\title{
Chemical-nutritional composition of maniçoba (Manihot sp.) and its relationship with soil chemical characteristics
}

\author{
Alexandro Pereira Andrade ${ }^{1}$, Alberício Pereira de Andrade ${ }^{2,8}$, Divan Soares da Silva ${ }^{3,8}$, Edson \\ Mauro Santos ${ }^{4,8}$, Ivandro de França da Silva ${ }^{5}$, Elizanilda Ramalho do Rêgo ${ }^{6,8}$, Riselane de \\ Lucena Alcântara Bruno $0^{7,8}$
}

\footnotetext{
${ }^{1}$ Programa de Pós-Graduação em Zootecnia - PPGZ - UFPB, Areia, PB, Brasil.

${ }^{2}$ PPGZ - UFPB, Areia, PB e PPGCAP/UAG - UFRPE, Garanhuns, PE, Brasil.

${ }^{3}$ PPGZ - UFPB, Areia, PB e PPGZ/CSTR - UFCG, Patos, PB, Brasil.

${ }^{4}$ Departamento de Zootecnia, UFPB, Areia, PB, Brasil.

${ }^{5}$ Departamento de Solos e Engenharia Rural, UFPB, Areia, PB, Brasil.

${ }^{6}$ Departamento Ciências Fundamentais e Social, UFPB, Areia, PB, Brasil.

${ }^{7}$ Departamento de Fitotecnia e Ciências Ambientais, UFPB, Areia, PB, Brasil.

${ }^{8}$ Researcher (CNPq).
}

\begin{abstract}
The objective of this study was to evaluate the chemical composition of leaves of maniçoba (Manihot sp.) according to their development stage and their relationship with the soil characteristics. For this purpose, plants in their natural growth areas in the semiarid region of Paraíba State, Brazil, were sampled. Leaves of maniçoba collected in five different locations at four different development stages were harvested and characterized: expanding leaf, completely expanded leaf, leaf at the beginning of senescence and a pool (mixture of all leaves). The evaluated traits were: dry matter, crude protein, neutral detergent fiber, acid detergent fiber, neutral detergent insoluble protein, acid detergent insoluble protein, ash, lignin, cellulose, hemicellulose, nitrogen, potassium, phosphorus, sulfur and sodium. The experimental design adopted was completely randomized, in a $4 \times 5$ factorial arrangement: four leaf development stages and five locations, respectively; each plot had 10 replications. There was interaction effect between leaf development stage and locations on dry matter, crude protein, neutral detergent insoluble protein and acid detergent insoluble protein. The results for neutral detergent fiber of leaves at the beginning of senescence were higher than other treatments and similar to the pool, while the acid detergent fiber content of the leaves in early senescence was higher than those of other treatments, averaging $34.8 \%$. Crude protein content had its highest percentage in expanding leaves, averaging $23.0 \%$. Nitrogen, potassium and sodium data showed interaction between the leaf types and locations of harvest, while phosphorus and sulfur did not show interaction. The chemical and mineral composition of maniçoba leaves range according to their development phase and according to their soil and climatic conditions in places of natural occurrence, with a tendency towards reduction of nitrogen and phosphorus as they approach senescence.
\end{abstract}

Key Words: caatinga, forage, semiarid, xerophilous plants

\section{Introduction}

The Brazilian semiarid region encompasses an area of 92.5 million hectares, which corresponds to approximately $10 \%$ of the territory of the country, where animal husbandry stands out as one of the main activities of its economy. Goat-sheep farming is one the most important socioeconomic alternatives, mainly in family agriculture. However, this activity has been limited by the low forage availability, especially during the long dry periods and the inappropriate animal management, misuse of the existing forage resources of the region and poor use of the forages

Received March 26, 2013 and accepted January 30, 2014 Corresponding author: alexandro_andrade@hotmail.com http://dx.doi.org/10.1590/S1516-35982014000400001

Copyright $(C 2014$ Sociedade Brasileira de Zootecnia. This is an Open Access article distributed under the terms of the Creative Commons Attribution Non-Commercial License, which permits unrestricted non-commercial use, distribution, and reproduction in any medium, provided the original work is properly cited. conserved as hay and silage, in addition to the high cost of rations.

In the arid and semiarid lands, the temperature, solar radiation and the amount of nutrient in the ecosystem do not vary much throughout the year. Rainfall usually happens in discontinuous and discreet events, in the form of short-term pulses (Noy-Meir, 1973).

The caatinga, predominant vegetation type in the Brazilian semiarid, is a plant formation rich in diversities of species of both woody and annual herbaceous plants. Classifying the caatinga is a great challenge, requiring evaluation of the variations in its physiognomy resulting from the main interaction between soil and climate, in addition to the anthropogenic interference. The vegetation established in this environment reflects heterogeneity in its physiognomic types, in its floristic composition, in its relative abundance and in the population dynamics (Araujo et al., 2007). 
Andrade et al. (2010) reported that the little knowledge of the dynamics of phytomass accumulation of most of the caatinga species is an obstacle to greater advances in the cultivation of forages of excellent quality in the region.

In this context is maniçoba (Manihot sp.), a plant of great adaptive ability, widespread in almost all the Brazilian semiarid territory, vegetating in several types of soil and relief. It is highly resistant to long dry periods for presenting roots with a large reserve capability (Soares, 1995).

According to Van Soest (1994), the distribution of several chemical components in plants varies according to the tissues and organs, due to the specificity of the physical arrangement of plant cells. Modesto et al. (2004) found that no isolated factor affects forage quality as much as the plant developmental stage. However, the environment in which the plant develops changes the impact of age.

For Hardesty, (1988), among the climate factors, temperature has a major role in the forage quality. High temperatures compromise the digestibility of the forage dry matter of both grass and legume plants and stems and leaves.

It is well known that there are many studies on the chemical composition of maniçoba. Nevertheless, more research should be conducted because of the large genetic and environmental variation.

The nutritional composition of maniçoba varies according to the time of the year, the form of conservation of the material, the ratios between the parts of the plant, among other factors. This plant is composed of 25.8 to $93.3 \%$ dry matter (DM); 11.9 to $16.8 \%$ crude protein $(\mathrm{CP})$; 47.1 to $58.6 \%$ neutral detergent fiber (NDF); and 28.7 to $44.4 \%$ acid detergent fiber (ADF) (Barros et al., 1990; França et al., 2010; Vasconcelos et al., 2010).

In view of this scenario, the objective of this study was to evaluate the chemical composition of leaves of maniçoba according to their developmental stage and their relationship with the soil characteristics in its natural growth areas in the semiarid region of Paraíba State, Brazil.

\section{Material and Methods}

This experiment was carried out in the municipalities of Barra de Santa Rosa, Picuí and Pedra Lavrada (microregion Curimataú Paraibano) and Monteiro and Campina Grande (micro-region Cariri Paraibano).

The soils collected from the municipalities of Barra de Santa Rosa, Picuí, Monteiro and Campina Grande were classified as: Haplic Planosol, Entisol, Chromic Luvisol and Neossol, respectively, according to Campos and Queiroz (2006), and the soils from Pedra Lavrada are a type similar to the soil from Picuí.
We selected 10 relatively close maniçoba plants of similar size based on their height, stem diameter and crown in the caatinga areas of every municipality, sampling the leaves in their different developmental phases. In the sampled leaves, we removed the petiole and only utilized the limbus, because it accounted for a higher content of nutrients in this organ. The leaf development phases sampled were: expanding leaf (EL), completely expanded leaf (CEL), leaf at the beginning of senescence (LBS) and a pool (composed of expanding leaf + completely expanded leaf + leaf at the beginning of senescence).

Samplings were conducted on July 19 and 20, 2009, since these plants were in full vegetative stage, i.e., the same plant contained different stages of leaf development. Thus, on the day of sampling, the selected plants had leaves at different stages of growth, and so the collection was assembled. Climatic data (Table 1) were obtained from the database of AESA (Agência Executiva de Gestão das Águas da Paraíba).

Leaf samples were subsequently placed in labeled plastic bags which were put in thermal boxes with ice before being taken to the Laboratory of Animal Nutrition of UFPB for analysis of dry matter (DM), mineral matter (MM), crude protein $(\mathrm{CP})$, neutral detergent insoluble protein (NDIP) and acid detergent insoluble protein (ADIP), according to the methodology of Silva and Queiroz (2002).

To determine neutral detergent fiber (NDF), acid detergent fiber (ADF) and lignin, we utilized the methodology proposed by Van Soest (1967). Cellulose was determined by the difference between ADF and lignin, while the result of hemicellulose was calculated as the difference between NDF and ADF. Nitrogen, phosphorus, potassium and sulfur contents of the leaves sampled were determined in the Laboratory of Plant Tissue Analysis of UFPB according to the methodology proposed by Tedesco et al. (1995).

In each site of collection of maniçoba leaves, we also collected five samples of the soil around the base of each plant at a depth of 0 to $20 \mathrm{~cm}$ and conditioned them in plastic buckets. After sampling, the soil was homogenized and we took a composite sample of each site, identified them and took them to the Laboratory of Soil Fertility Chemistry of CCA - UFPB for physical and fertility analyses (Tables 2 and 3).

The data were subjected to analysis of variance $(\mathrm{P} \leq 0.05)$ in a completely randomized design in a $4 \times 5$ factorial arrangement: four leaf development stages and five locations, respectively. Each plot had 10 replications. When significant effects were detected, the means were compared by Tukey's test $(\mathrm{P} \leq 0.05)$. Statistical analyses were performed on software Genes (Cruz, 2006). 
Table 1 - Climatic data of each site from January to July 2009

\begin{tabular}{lcccccccccc}
\hline Sites & \multicolumn{2}{c}{ Barra de Santa Rosa } & \multicolumn{2}{c}{ Campina Grande } & \multicolumn{2}{c}{ Monteiro } & \multicolumn{2}{c}{ Pedra Lavrada } \\
\hline Months & $\mathrm{P}$ & $\mathrm{T}$ & $\mathrm{P}$ & $\mathrm{T}$ & $\mathrm{P}$ & $\mathrm{T}$ & $\mathrm{P}$ & $\mathrm{T}$ & $\mathrm{P}$ & $\mathrm{T}$ \\
\hline January & 12.5 & 24.8 & 34.9 & 23.9 & 51.7 & 24.2 & 23.6 & 24.5 & 29.7 & 26.1 \\
February & 37.2 & 24.7 & 120.8 & 25.0 & 134.1 & 23.5 & 59.0 & 24.3 & 50.8 & 25.1 \\
March & 74.3 & 24.5 & 35.7 & 24.7 & 29.3 & 24.6 & 102.9 & 24.0 & 88.1 & 25.0 \\
April & 79.0 & 24.1 & 139.0 & 24.5 & 221.3 & 23.6 & 89.6 & 23.7 & 85.7 & 24.8 \\
May & 47.6 & 23.3 & 57.6 & 23.3 & 270.4 & 22.7 & 31.5 & 22.9 & 36.8 & 24.0 \\
June & 41.4 & 22.3 & 88.8 & 22.3 & 38.5 & 21.6 & 20.6 & 21.9 & 19.7 & 23.3 \\
July & 33.4 & 21.7 & 95.0 & 20.1 & 22.9 & 21.3 & 15.0 & 21.5 & 10.6 & 22.0 \\
\hline
\end{tabular}

$\mathrm{P}$ - precipitation $(\mathrm{mm}) ; \mathrm{T}$ - mean temperature $\left({ }^{\circ} \mathrm{C}\right)$.

Table 2 - Physical analysis of soil in each site of collection

\begin{tabular}{|c|c|c|c|c|c|}
\hline Sites & Barra de Santa Rosa & Picuí & Pedra Lavrada & Monteiro & Campina Grande \\
\hline Sand (g/kg) & 811 & 801 & 822 & 629 & 797 \\
\hline Silt (g/kg) & 118 & 137 & 114 & 212 & 95 \\
\hline Clay $(\mathrm{g} / \mathrm{kg})$ & 71 & 62 & 64 & 159 & 108 \\
\hline Dispersed clay (g/kg) & 25 & 25 & 13 & 155 & 102 \\
\hline Degree of flocculation $\left(\mathrm{kg} / \mathrm{dm}^{3}\right)$ & 648 & 597 & 797 & 25 & 56 \\
\hline Soil density $\left(\mathrm{g} / \mathrm{cm}^{3}\right)$ & 1.31 & 1.22 & 1.30 & 1.22 & 1.38 \\
\hline Particle density $\left(\mathrm{g} / \mathrm{cm}^{3}\right)$ & 2.62 & 2.7 & 2.69 & 2.75 & 2.58 \\
\hline Total porosity $\left(\mathrm{m}^{3} / \mathrm{m}^{3}\right)$ & 0.50 & 0.55 & 0.52 & 0.56 & 0.46 \\
\hline Textural class & Loamy sandy & Loamy sandy & Loamy sandy & Loamy sandy & Loamy sandy \\
\hline
\end{tabular}

Table 3 - Analysis of soil fertility in each site of collection

\begin{tabular}{|c|c|c|c|c|c|}
\hline Sites & Barra de Santa Rosa & Picuí & Pedra Lavrada & Monteiro & Campina Grande \\
\hline $\mathrm{pH}\left(\mathrm{H}_{2} \mathrm{O}\right)$ & 5.93 & 6.12 & 5.62 & 6.12 & 6.78 \\
\hline $\mathrm{P}\left(\mathrm{mg} / \mathrm{dm}^{3}\right)$ & 3.10 & 4.37 & 3.11 & 1.19 & 3.55 \\
\hline $\mathrm{K}^{+}\left(\mathrm{cmol} / \mathrm{dm}^{3}\right)$ & 0.68 & 0.41 & 0.18 & 0.36 & 0.70 \\
\hline $\mathrm{Ca}^{2+}+\mathrm{Mg}^{2+}\left(\mathrm{cmol} / \mathrm{dm}^{3}\right)$ & 6.70 & 6.65 & 4.75 & 8.20 & 3.50 \\
\hline $\mathrm{Ca}^{2+}\left(\mathrm{cmol} / \mathrm{dm}^{3}\right)$ & 5.10 & 5.10 & 4.10 & 6.90 & 2.10 \\
\hline $\mathrm{Mg}^{2+}\left(\mathrm{cmol} / \mathrm{dm}^{3}\right)$ & 1.60 & 1.55 & 0.65 & 1.30 & 1.40 \\
\hline $\mathrm{H}^{+}+\mathrm{Al}^{3+}\left(\mathrm{cmol} / \mathrm{dm}^{3}\right)$ & 1.15 & 1.48 & 4.04 & 2.15 & 1.16 \\
\hline Carbon $(\mathrm{g} / \mathrm{kg})$ & 6.10 & 5.92 & 8.06 & 8.26 & 5.13 \\
\hline Organic matter $(\mathrm{g} / \mathrm{kg})$ & 10.52 & 10.21 & 13.89 & 14.24 & 8.84 \\
\hline Sum of bases $\left(\mathrm{cmol} / \mathrm{dm}^{3}\right)$ & 7.76 & 7.38 & 5.10 & 8.90 & 4.81 \\
\hline Cation exchange $\left(\mathrm{cmol} / \mathrm{dm}^{3}\right)$ & 8.91 & 8.86 & 9.14 & 11.05 & 5.97 \\
\hline Base saturation $(\%)$ & 87.09 & 83.30 & 55.80 & 80.54 & 80.57 \\
\hline
\end{tabular}

\section{Results and Discussion}

There was significant interaction between leaf development phases and locations $(\mathrm{P}<0.05)$ on $\mathrm{DM}, \mathrm{CP}$, NDIP and ADIP (Table 4). The dry matter of the plants sampled in Monteiro and Campina Grande showed high values in all leaf development stages. The crude protein content of expanding leaves (EL) was significantly higher $(\mathrm{P}<0.05)$ in the leaves collected in Barra de Santa Rosa, Monteiro and Campina Grande as compared with the other locations. The mean values for NDIP in EL did not differ between samples collected in Campina Grande, Monteiro and Pedra Lavrada. For the completely expanded leaves (CEL), there was no significant difference in Campina Grande, Monteiro and Barra de Santa Rosa (data not shown).
As to the ADIP values, location had an effect on expanding leaves and leaves at the beginning of senescence (LBS); leaves collected in Campina Grande showed higher means than the other municipalities. The samples of EL and leaves from the pool had similar values, and the highest values were verified in the leaves sampled in Monteiro and Campina Grande.

The differences found in dry matter content were most likely caused by the climatic variability found in every location, in addition to the differences between plants found in the experimental areas (Table 1).

The plant accumulates dry matter in the form of carbohydrates, proteins, lipids and mineral, which ensures a supply of carbon and energy for its development or maintenance (Pimentel, 1998). Thus, with the 
Table 4 - Mean values of dry matter, crude protein, neutral detergent insoluble protein and acid detergent insoluble protein of maniçoba leaves at different development stages and locations in the semiarid of Paraíba

\begin{tabular}{|c|c|c|c|c|}
\hline \multirow{2}{*}{ Sites } & \multicolumn{4}{|c|}{ Leaf development stages } \\
\hline & Expanding leaf & Completely expanded leaf & Leaf at the beginning of senescence & Pool \\
\hline \multicolumn{5}{|c|}{ Dry matter $(\%)$} \\
\hline Picuí & $24.23 \mathrm{aAB}$ & $24.16 \mathrm{aB}$ & $25.85 \mathrm{aA}$ & $24.66 \mathrm{aAB}$ \\
\hline Pedra Lavrada & $23.06 \mathrm{aBC}$ & $21.85 \mathrm{aB}$ & $21.75 \mathrm{aB}$ & $21.73 \mathrm{aC}$ \\
\hline Monteiro & $25.89 \mathrm{aA}$ & $28.92 \mathrm{aA}$ & $25.93 \mathrm{aA}$ & $27.42 \mathrm{aA}$ \\
\hline \multicolumn{5}{|c|}{$\mathrm{CV}(\%)=9.23$} \\
\hline \multicolumn{5}{|c|}{ Crude protein $(\%)$} \\
\hline Barra de Santa Rosa & $26.35 \mathrm{aA}$ & $25.33 \mathrm{aA}$ & $21.99 \mathrm{bB}$ & $24.26 \mathrm{abA}$ \\
\hline Picuí & $18.96 \mathrm{aB}$ & $17.95 \mathrm{aC}$ & $17.55 \mathrm{aC}$ & $17.96 \mathrm{aBC}$ \\
\hline Pedra Lavrada & $19.42 \mathrm{aB}$ & $18.73 \mathrm{aBC}$ & $12.89 \mathrm{bD}$ & $16.94 \mathrm{aC}$ \\
\hline Monteiro & $23.79 \mathrm{aA}$ & $21.49 \mathrm{abB}$ & $10.91 \mathrm{cD}$ & $20.09 \mathrm{bB}$ \\
\hline Barra de Santa Rosa & $10.15 \mathrm{abBC}$ & $11.10 \mathrm{aAB}$ & $11.03 \mathrm{aAB}$ & $8.87 \mathrm{bB}$ \\
\hline Picuí & $8.15 \mathrm{aC}$ & $8.56 \mathrm{aC}$ & $9.47 \mathrm{aB}$ & $8.98 \mathrm{aB}$ \\
\hline Pedra Lavrada & $10.20 \mathrm{aABC}$ & $9.66 \mathrm{aBC}$ & $6.45 \mathrm{bC}$ & $9.11 \mathrm{aB}$ \\
\hline Monteiro & $11.76 \mathrm{aAB}$ & $10.63 \mathrm{aABC}$ & $4.29 \mathrm{bC}$ & $10.46 \mathrm{aAB}$ \\
\hline Campina Grande & $12.38 \mathrm{aA}$ & $11.92 \mathrm{aA}$ & $11.78 \mathrm{aA}$ & $12.54 \mathrm{aA}$ \\
\hline \multicolumn{5}{|c|}{$\mathrm{CV}(\%)=18.19$} \\
\hline \multicolumn{5}{|c|}{ Acid detergent insoluble protein (\%) } \\
\hline Barra de Santa Rosa & $4.33 \mathrm{bBC}$ & $4.52 \mathrm{bB}$ & $6.43 \mathrm{aAB}$ & $4.96 \mathrm{bB}$ \\
\hline Picuí & $3.42 \mathrm{bC}$ & 4.17abB & $5.30 \mathrm{aBC}$ & $4.52 \mathrm{abB}$ \\
\hline Pedra Lavrada & $4.11 \mathrm{aBC}$ & $4.33 \mathrm{aB}$ & $4.79 \mathrm{aC}$ & $4.45 \mathrm{aB}$ \\
\hline Monteiro & $5.02 \mathrm{bB}$ & $6.81 \mathrm{aA}$ & $4.41 \mathrm{bC}$ & $6.63 \mathrm{aA}$ \\
\hline Campina Grande & $6.91 \mathrm{aA}$ & $7.43 \mathrm{aA}$ & $7.56 \mathrm{aA}$ & $7.78 \mathrm{aA}$ \\
\hline \multicolumn{5}{|c|}{$\mathrm{CV}(\%)=23.47$} \\
\hline
\end{tabular}

Means followed by the same letter, lowercase between rows and uppercase between columns, do not differ by Tukey's test ( $\mathrm{P} \leq 0.05$ ).

$\mathrm{CV}$ - coefficient of variation.

vegetative development there is greater accumulation of photoassimilates, especially in the form of carbohydrates and their concentration of minerals in senescent leaves.

Evaluating the nutritional value of maniçoba subjected to a double-pruning system, Ferreira et al. (2009) found DM percentages of 34.6 and 22.7 for the 1st and 2 nd pruning, respectively. Dry matter tends to reduce with plant growth cycle, and this probably occurred with the samples from Barra de Santa Rosa, Picuí and Pedra Lavrada, which by chance were collected at the end of the annual growth cycle, coinciding with the end of the rainy period.

Using maniçoba to produce silage with a co-product from winemaking, Dantas et al. (2008) found 26\% DM in tender leaves and branches, while Albuquerque (2006) reported a dry matter content of $30.99 \%$.

The crude protein values of EL varied between 19.0 and $26.5 \%$ in the leaves sampled in Picuí and Pedra Lavrada, whereas in LBS the variation was from 10.9 to $25.4 \% \mathrm{CP}$ in the samples collected in Monteiro and Pedra Lavrada. This variation in the $\mathrm{CP}$ contents of leaves between the different places may be linked to the soil and climatic conditions of each location, which can also affect the digestibility of nutrients such as nitrogen and phosphorus. In general, the soils from the Brazilian semiarid are deficient in nutrients like nitrogen and phosphorus due to their low organic matter content (Sampaio et al., 1995).

The highest OM contents were found in the soils from Monteiro and Pedra Lavrada, which showed 14.24 and $13.89 \%$, respectively (Table 3 ). However, the leaves sampled in Barra de Santa Rosa and Campina Grande showed the highest $\mathrm{CP}$ values and did not have the same relationship with the OM levels in the soil. However, the degree of flocculation in the soil sampled in Campina Grande is too low (56 kg/ $\mathrm{dm}^{3}$; Table 2), and this is related to the low $\mathrm{OM}$ content and elevated density of the soil $\left(1.38 \mathrm{~g} / \mathrm{cm}^{3}\right)$. This can probably be explained by the animal trampling, which causes the soil to be more compressed, reducing the degree of flocculation.

The results from the soil analysis in the area of Monteiro showed a higher OM content and consequently low degree 
of flocculation caused by the high amount of dispersed clay. Seemingly related to climate conditions in this area, the OM decomposition is lower and so nitrogen availability in the soil is also lower.

The literature shows different CP percentages, with variations between 11 and $18 \%$ in hay, reaching higher values depending on the plant organs collected and on the season of the year. Evaluating tender leaves and branches of maniçoba, Soares (1995) found $20.9 \%$ CP, which is close to the values found in the present study. Vasconcelos et al. (2010) obtained $11.09 \%$ CP in maniçoba hays cultivated in Campina Grande. Evaluating the nutritional value of hay in Cubatí City, in Curimataú Paraibano, Azevedo (2008) found values between 18.8 and $8.7 \% \mathrm{CP}$, wherein the highest percentages were obtained right after the first rainfalls, when plants started to shoot, and the content reduced a few months after fruits have ripened and the leaves have developed.

Neutral detergent insoluble protein values were 10.5, 10.4, 8.61 and $10.0 \%$ for EL, CEL, LBS and pool of leaves, respectively. This demonstrated that 46.0, 47.5, 48.0 and $48.1 \%$ of the crude protein are linked to the NDF, i.e., to the cell wall. Although the maniçoba leaves in this study presented an overall mean of $20.9 \% \mathrm{CP}$, on average, $47 \%$ of this protein are bound to the cell wall, leading to a slow degradation in the rumen of these animals.

Acid detergent insoluble protein values were 4.8, 5.5, 5.7 and $5.7 \%$ for EL, CEL, LBS and leaves from the pool, respectively. These results indicate that the ADIP/CP ratios were on average 20.9, 25.0, 34.2 and 27.5\% EL, CEL, LBS of the pool, thereby demonstrating that more than $30 \%$ of the crude protein is bound to the cellulose or to the lignin from the cell wall; this protein portion is indigestible in the rumen of animals. These results corroborate Albuquerque (2006), who reported NDIP and ADIP values of 55.77 and $24.59 \% \mathrm{CP}$, which are close to our results.
The results for MM, NDF, ADF, lignin, cellulose and hemicellulose showed no interaction $(\mathrm{P}>0.05)$ of treatments and sampling sites (Table 5).

The average MM in the LBS was higher $(\mathrm{P}<0.05)$ when compared with the other leaf development stages. In the leaves sampled in Picuí, this value was higher $(\mathrm{P}<0.05)$ as compared with the other sites.

The results for NDF (Table 5) indicate that the LBS obtained higher values than the other treatments, but these values were not different from the leaves of the pool, whereas for ADF the LBS values were higher than all other treatments, averaging $34.8 \%$. For lignin, LBS achieved a significantly higher mean $(\mathrm{P}<0.05)$ as compared with the other treatments. The cellulose results did not differ between treatments, whereas for hemicellulose, expanding and expanded leaves had similar values.

The results for mineral matter indicate a trend towards concentration of minerals in the LBS, possibly due to the accumulation of minerals like potassium and calcium. According to Nunes Irmão et al. (2008), the MM content of plants is not an appropriate indicator to verify the inorganic nutrients because of the variable nature of this material; among them, silica.

Similar results were obtained by Ferreira et al. (2009), who found MM percentages of 6.8 and 7.45 when they assessed the nutritional value of maniçoba subjected to double pruning, for the 1st and 2nd prunings, respectively. Using maniçoba for the production of silage with coproduct from winemaking as additive, Dantas et al. (2008) found $7.21 \% \mathrm{MM}$ in the leaves and branches. However, Albuquerque (2006) found 7.74\% MM.

Gonçalves et al. (2003) mentioned that the advancement in the age of the leaves of forage plants results in increase in the cell wall components and consequently reduces the digestibility coefficients and crude protein contents.

Table 5 - Mean values of ash, neutral detergent fiber (NDF), acid detergent fiber (ADF), lignin, cellulose and hemicellulose of maniçoba leaves at different leaf development stages and locations in the semiarid of Paraíba

\begin{tabular}{|c|c|c|c|c|c|c|}
\hline Treatments/Sites & $\operatorname{Ash}(\%)$ & NDF $(\%)$ & $\operatorname{ADF}(\%)$ & Lignin $(\%)$ & Cellulose $(\%)$ & Hemicellulose (\%) \\
\hline Expanding leaf & $6.95 \mathrm{c}$ & $37.48 b$ & $28.52 \mathrm{c}$ & $11.80 \mathrm{c}$ & $16.72 \mathrm{a}$ & $8.96 \mathrm{a}$ \\
\hline Completely expanded leaf & $7.34 \mathrm{bc}$ & $37.39 \mathrm{~b}$ & $29.51 \mathrm{c}$ & $13.98 \mathrm{bc}$ & $15.53 \mathrm{a}$ & $7.87 \mathrm{ab}$ \\
\hline Leaf at the beginning of senescence & $8.11 \mathrm{a}$ & $39.37 \mathrm{a}$ & $34.79 \mathrm{a}$ & $17.67 \mathrm{a}$ & $17.13 \mathrm{a}$ & $4.57 \mathrm{c}$ \\
\hline Pool & $7.56 b$ & $38.56 \mathrm{ab}$ & $32.00 \mathrm{~b}$ & $14.80 \mathrm{~b}$ & $17.19 \mathrm{a}$ & $6.56 b$ \\
\hline HSD Treatments & 0.50 & 1.47 & 1.91 & 2.23 & 1.86 & 1.75 \\
\hline Barra de Santa Rosa & $7.52 b$ & $38.45 \mathrm{a}$ & $29.04 b$ & $11.32 \mathrm{c}$ & $17.71 \mathrm{ab}$ & $9.41 \mathrm{a}$ \\
\hline Picuí & $8.58 \mathrm{a}$ & $37.87 \mathrm{a}$ & $29.35 b$ & $16.12 \mathrm{a}$ & $13.24 \mathrm{c}$ & $8.51 \mathrm{a}$ \\
\hline Pedra Lavrada & $6.78 \mathrm{c}$ & $39.59 a$ & $31.82 \mathrm{a}$ & $13.24 b c$ & $18.58 \mathrm{a}$ & $7.77 \mathrm{ab}$ \\
\hline Monteiro & $7.79 b$ & $36.05 b$ & $32.68 \mathrm{a}$ & $15.06 \mathrm{ab}$ & $17.62 \mathrm{ab}$ & $3.37 \mathrm{c}$ \\
\hline Campina Grande & $6.79 \mathrm{c}$ & $39.03 \mathrm{a}$ & $33.13 \mathrm{a}$ & $17.07 \mathrm{a}$ & $16.06 \mathrm{~b}$ & $5.90 \mathrm{~b}$ \\
\hline HSD Sites & 0.59 & 1.75 & 2.28 & 2.65 & 2.21 & 2.08 \\
\hline
\end{tabular}

Means followed by the same letter in each column do not differ significantly by Tukey's test $(\mathrm{P} \leq 0.05)$. HSD - honestly significant difference. 
Additionally, the environment in which plants grow can modify the anatomy of leaves and their chemical composition as well. According to Van Soest (1994), factors like plant species, temperature, light intensity, water availability, maturity and type of harvesting affect the chemical composition and consequently the energy availability of feeds.

Studying the characterization of maniçoba hay in the micro-region Curimataú Paraibano, Azevedo (2008) found that the mean values of NDF and ADF over the year varied from 41.9 to $54.2 \% \mathrm{NDF}$ and 29.7 to $46.3 \% \mathrm{ADF}$. According to this author, the quality of this forage plant is higher after the beginning of the rainy period, which is also the ideal moment for haymaking because of the fewer indigestible components.

França et al. (2010) reported average NDF and ADF of 43.0 and $30.9 \%$ in a collection of leaves + branches for haymaking. Evaluating wild-cassava leaves and branches, Vasconcelos et al. (2010) obtained mean percentages of 50.4 and $31.4 \%$ for NDF and ADF, respectively; these NDF values were much higher than those found in our study.

According to Wilson (1994) when the elongation is finished, the lignification process begins; starting by the vertices of the cells, continuing through the middle lamella/ primary wall until the secondary cell wall. As the maniçoba grows, the leaves at the beginning of senescence show a higher lignin content and consequently increased cell wall, which is typical of woody species, suggesting that plants should be cut before they start to bear fruit, because the concentration and digestibility of nutrients decrease as the plant develops.

The average lignin percentages of 11.0 and $17.10 \%$ respectively found by França et al. (2010) and Barros et al.
(1990) can be explained by the phenological stage of the plant in the collection period, since in this study the EL presented an average of $11.8 \%$, while LBS averaged $17.7 \%$.

The nitrogen and potassium results showed significant interaction $(\mathrm{P}<0.05)$ between leaf development phases and locations (Table 6).

Nitrogen levels in EL and CEL sampled in Campina Grande were similar to Monteiro and higher than the other locations. Potassium contents showed some variability in the results, both in the leaf development phases and regarding the sampling sites. Overall, in LBS there was a trend to increase the concentration of this nutrient. Leaves sampled in Monteiro and Pedra Lavrada had a trend towards reduction of this nutrient, due to the soil and climate conditions, which is reflected in the lower values in the soils collected from these locations.

According to Wardlaw (1990), as new leaves develop, the photosynthetic activity of the old ones is reduced, and they start senescence to retranslocate nutrients - especially nitrogen - to the newer ones. This fact occurs in the maniçoba leaves, because older leaves have a lower nitrogen content. This difference between the nitrogen values is probably due to genetic differences between plants in the pasture, since there is no relationship with the soil types.

Comparing the results for crude protein and nitrogen, they showed similar trends, with divergence only in the values presented. This difference in values was probably caused by the sensitivity in the methodology described by Tedesco et al. (1995) in the determination of nitrogen, because this analysis requires the use of hydrogen peroxide during the digestion of the material in the hood, and the

Table 6 - Mean values of nitrogen and potassium of maniçoba leaves at different leaf development stages and locations in the semiarid of Paraíba

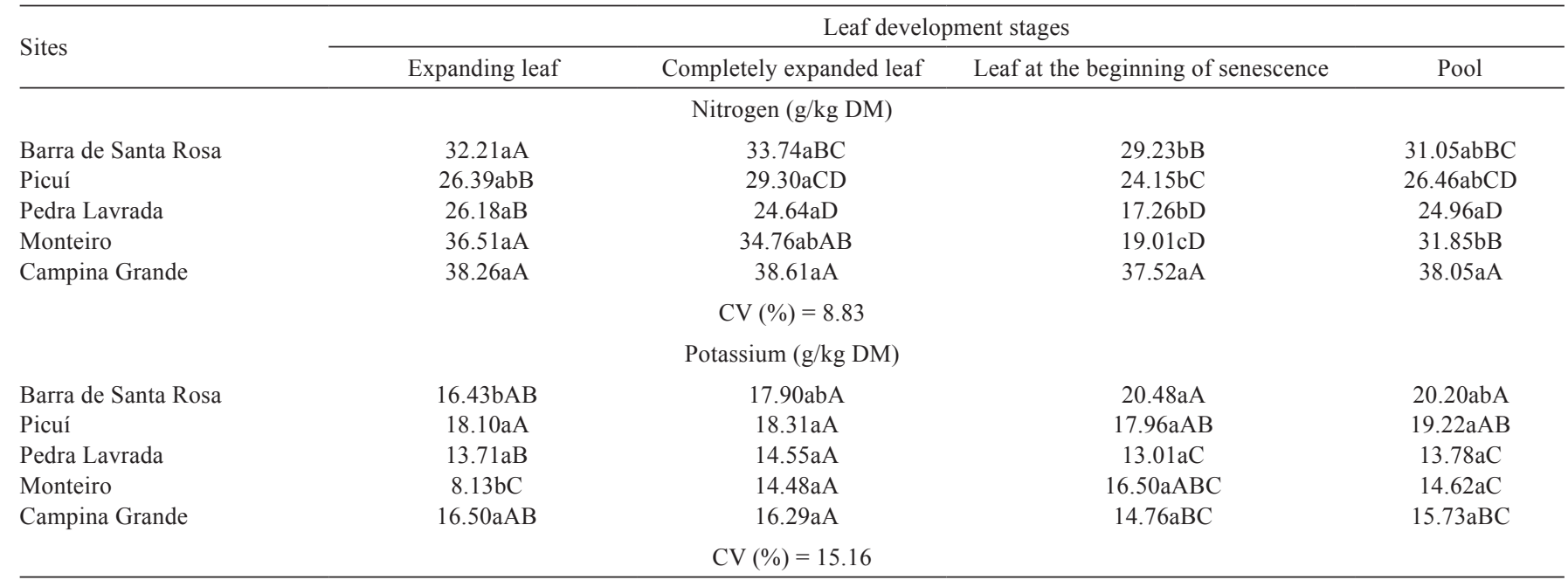

Means followed by the same letter, lowercase between rows and uppercase between columns, do not differ by Tukey's test (P $\leq 0.05$ ).

$\mathrm{CV}$ - coefficient of variation. 
digested material is subsequently diluted for distillation and titration of the samples.

Nutrient translocation is an essential physiological process common to all plants, including those adapted to the semiarid, as in the case of maniçoba, especially because of the low water availability in the most part of the year.

The highest potassium contents were found in leaves sampled in Barra de Santa Rosa and Picuí. However, the soil chemical analysis revealed that Barra de Santa Rosa and Campina Grande had lower concentrations of this mineral in the soil (Table 3).

The potassium levels found in the soils are considered from intermediate to very high. The values found in Pedra Lavrada are intermediate $\left(0.1-0.3 \mathrm{cmolc} / \mathrm{dm}^{3}\right)$, whereas the values obtained in Barra de Santa Rosa and Campina Grande are considered very high $\left(>0.6 \mathrm{cmolc} / \mathrm{dm}^{3}\right)$. Although the sampling area in Campina Grande contained more potassium in the soil, there was greater absorption by the plants. This fact was probably caused by the genetic diversity of the plant population in that area, and a genetic characterization of these plants could prove this hypothesis.

According to Larcher (2000), plants require this nutrient at between 5 and $20 \mathrm{~g} / \mathrm{kg}$ DM. The maniçoba leaves had on average $14.6,16.3,16.5$ and $16.7 \mathrm{~g} / \mathrm{kg}$ DM for EL, CEL, LBS and leaves from the pool, respectively. These results corroborate those described by the author.

Assessing the mineral composition of maniçoba with nitrogen doses, Parente et al. (2007) obtained potassium values that varied between 7.67 and $8.58 \mathrm{~g} / \mathrm{kg}$ dry matter, which are lower numbers than those found in this study. According to these authors, the variabilities are due to the initial differences of plants, as well as the irregular rainfalls during the experimental period.

Regarding the phosphorus and sulfur results, there was no significant interaction $(\mathrm{P}>0.05)$ between the leaf development phases and locations (Table 7). The phosphorus values indicated that the average EL was higher than the LBS, which happened mainly because of the translocation of this mineral from senescing leaves to young leaves, whereas for sulfur the average expanded leaves was inferior to the pool, but not different from EL and LBS.

According to Larcher (2000), plants require phosphorus at between 1.5 and $3.0 \mathrm{~g} / \mathrm{kg} \mathrm{DM}$, on average, which demonstrates that EL, CEL and the leaves from the pool had higher values than their requirements, probably because of the nutrient availability found in the soils.

According to the soil fertility results (Table 3), Picuí had the highest phosphorus content $\left(4.37 \% \mathrm{mg} / \mathrm{dm}^{3}\right)$ and average value in the leaves $(4.28 \mathrm{~g} / \mathrm{kg})$. However, this ratio was not constant. Monteiro city had a lower phosphorus
Table 7 - Mean values of phosphorus and sulfur of maniçoba leaves at different leaf development stages and locations in the semiarid of Paraíba

\begin{tabular}{lcc}
\hline Treatments/Sites & Phosphorus $(\mathrm{g} / \mathrm{kg})$ & Sulfur $(\mathrm{g} / \mathrm{kg})$ \\
\hline Expanding leaf & $3.69 \mathrm{a}$ & $2.18 \mathrm{a}$ \\
Completely expanded leaf & $3.27 \mathrm{ab}$ & $2.15 \mathrm{a}$ \\
Leaf at the beginning of senescence & $2.91 \mathrm{~b}$ & $2.44 \mathrm{a}$ \\
Pool & $3.26 \mathrm{ab}$ & $2.52 \mathrm{a}$ \\
HSD Treatments & 0.49 & 0.38 \\
Barra de Santa Rosa & $3.53 \mathrm{~b}$ & $2.42 \mathrm{ab}$ \\
Picuí & $4.28 \mathrm{a}$ & $2.85 \mathrm{a}$ \\
Pedra Lavrada & $1.86 \mathrm{c}$ & $2.12 \mathrm{bc}$ \\
Monteiro & $3.49 \mathrm{~b}$ & $1.93 \mathrm{c}$ \\
Campina Grande & $3.25 \mathrm{~b}$ & $2.29 \mathrm{bc}$ \\
HSD Sites & 0.59 & 0.46 \\
\hline
\end{tabular}

Means followed by the same letter in each column do not differ significantly by Tukey's test $(\mathrm{P} \leq 0.05)$.

HSD - honestly significant difference.

content in the soil $\left(1.19 \mathrm{mg} / \mathrm{dm}^{3}\right)$ and elevated levels of this nutrient in the leaves $(3.49 \mathrm{~g} / \mathrm{kg})$.

The nitrogen-phosphorus-potassium contents in the ash content in plants can represent more than $70 \%$ of the percentage of ash, with 73.8, 71.0, 55.9 and $67.1 \%$ for EL, CEL, LBS and for the pool of leaves. These data demonstrate that younger leaves of maniçoba plants accumulate more minerals, especially nitrogen.

According to Fontes (2004), the main factors responsible for the different nutrient contents in the plant are its age, the organ analyzed, the time of the year and the soil and climatic conditions. No isolated factor influences the forage quality as much as the plant developmental stage; however, the environment in which the plant grows changes the impact of age (Modesto et al., 2004).

Evaluating the mineral composition of maniçoba with nitrogen doses, Parente et al. (2007) obtained phosphorus values ranging from 1.92 to $1.46 \mathrm{~g} / \mathrm{kg}$ dry matter.

Because of the reduced information on the mineral composition of maniçoba, we chose to compare it with the values of cassava leaves, since this plant is from the same family (Euphorbiacea). Evaluating five cassava cultivars and three harvesting times, Wobeto et al. (2006) found sulfur values between 2.8 and $4.1 \mathrm{~g} / \mathrm{kg}$ DM, whereas phosphorus varied between 2.4 and $3.3 \mathrm{~g} / \mathrm{kg}$ DM. Potassium values varied between 11.2 and $16.3 \mathrm{~g} / \mathrm{kg} \mathrm{DM}$, corroborating the information obtained in this experiment.

\section{Conclusions}

The mineral composition of maniçoba leaves varies according to their developmental stage, reducing nitrogen and phosphorus contents as senescence approaches. The 
nutritional composition of maniçoba leaves changes according to the phenological stage of their development and according to the soil and climatic conditions of the locations were they naturally grow. The crude protein contents are higher in expanding leaves than in those at the beginning of senescence, along with nitrogen contents of the leaf. On the other hand, mineral matter, neutral and acid detergent fibers and lignin increase along with leaf senescence. Based on this study, in vitro studies should be conducted to verify the translocation of nutrients in the plant, so that rational management of maniçoba leaves in animal feeding can be determined in the future.

\section{References}

Albuquerque, D. B. 2006. Efeito dos métodos de conservação de forragem sobre o valor nutritivo da maniçoba (Manihot epruinosa Pax \& Hoffmann), em caprinos e ovinos. Dissertação (M.Sc.). Universidade Federal Rural de Pernambuco, Recife.

Andrade, A. P.; Costa, R. G.; Santos, E. M. and Silva, D. S. 2010. Produção animal no semiárido: o desafio de disponibilizar forragem, em quantidade e com qualidade, na estação seca. Revista Tecnologia \& Ciência Agropecuária 4:1-14.

Araújo, E. L. Alburquerque, U. P. and Castro, C. C. 2007. Dynamics of Brazilian caatinga: a review concerning the plants, environment and people. Fuctional Ecosysyems and Communities 1:15-29.

Azevedo, D. O. 2008. Produção e valor nutritivo do feno de forrageiras de ocorrência natural na caatinga. Dissertação (M.Sc.). Universidade Federal da Paraíba, Areia.

Barros, N. N.; Salviano, L. M. C. and Kawas, J. R. 1990. Valor nutritivo de maniçoba para caprinos e ovinos. Pesquisa Agropecuária Brasileira 25:387-392.

Campos, M. C. C and Queiroz, S. B. 2006. Reclassificação dos perfis descritos no Levantamento exploratório - reconhecimento de solos do Estado da Paraíba. Revista de Biologia e Ciências da Terra $6: 45-50$.

Cruz, C. D. 2006. Programa Genes: Estatística experimental e matrizes. Editora UFV, Viçosa, MG, Brasil.

Dantas, F. R.; Araújo, G. G. L.; Silva, D. S.; Pereira, L. G. R.; Gonzaga Neto, S. and Tosto, M. S. L. 2008. Composição química e características fermentativas de silagens de maniçoba (Manihot sp.) com percentuais de co-produto de vitivinícolas desidratado. Revista Brasileira de Saúde e Produção Animal 9:247-257.

Ferreira, A. L.; Silva, A. F.; Pereira, L. G. R.; Braga, L. G. T.; Moraes, S. A. and Araújo, G. G. L. 2009. Produção e valor nutritivo da parte aérea da mandioca, maniçoba e pornunça. Revista Brasileira de Saúde e Produção Animal 10:983-990

Fontes, P. C. R. 2004. Diagnóstico do estado nutricional das plantas. 1.ed. UFV, Viçosa, MG, Brasil.

França, A. A.; Guim, A.; Batista, A. M. V.; Pimentel, R. M. M.; Ferreira, G. D. G. and Martins, I. D. S. L. 2010. Anatomia e cinética de degradação do feno de Manihot glaziovii. Acta Scientiarum Animal Sciences 32:131-138
Gonçalves, G. D.; Santos, G. T.; Jobim, C. B.; Damasceno, J. C.; Cecato, U. and Branco, A. F. 2003. Determinação do consumo, digestibilidade e frações protéicas e de carboidratos do feno de Tifton 85 em diferentes idades de corte. Revista Brasileira de Zootecnia 32:804-813.

Hardesty, L. H.; Box, T. W. and Malechek, J. C. 1988. Season of cutting affects biomass production by coppicing browse species of the Brazilian caatinga. Journal of Range Management 41:477-480.

Larcher, W. 2000. Ecofisiologia vegetal. Rima, Artes e Textos, São Carlos.

Modesto, E. C.; Santos, G. T.; Vilela, D.; Silva, D. C.; Faustino, J. O.; Detmann, E.; Zambom, M. A. and Marques, J. A. 2004. Caracterização químico-bromatológica da silagem do terço superior da rama de mandioca. Acta Scientiarum 26:137-146.

Noy-Meir, I. 1973. Desert ecosystems: environment and producers. Annual Reviews of Ecology and Systematics 4:25-51

Nunes Irmão, J.; Figueiredo, M. P.; Pereira, L. G. R.; Oliveira, B. M.; Rech, J. L.; Ferreira, J. Q. and Pereira, L. G. R. 2008. Composição química do feno da parte aérea da mandioca em diferentes idades de corte. Revista Brasileira de Saúde e Produção Animal 9:158-169.

Parente, H. N.; Silva, D. S.; Andrade, A. P.; Vieira Leite, M. L. M.; Viana, B. L.; Torres, A. S. and Santos, E. G. 2007. Influência da adubação nitrogenada sobre o crescimento inicial e composição química e mineral da maniçoba (Manihot sp.). Revista Cientifica de Produção Animal 9:102-110.

Pimentel, C. 1998. Metabolismo de carbono na agricultura tropical. 1.ed. Edur, Seropédica.

Sampaio, E. V. S. B.; Salcedo, I. H.; Silva, V. M. and Alves G. D. 1995. Capacidade de suprimento de $\mathrm{N}$ e resposta à fertilização de 20 solos de Pernambuco. Revista Brasileira de Ciência do Solo 20:269-279.

Silva, D. J. and Queiroz. A. C. 2002. Análise de alimentos: métodos químicos e biológicos. 3.ed. Editora UFV, Viçosa, MG, Brasil.

Soares, J. G. G. 1995. Cultivo de maniçoba (Manihot pseudoglaziovii) para a produção de forragem no semi-árido brasileiro. EMBRAPA/CPATSA, Petrolina. (EMBRAPA-CPATSA. Comunicado Técnico, 59).

Tedesco, M. J.; Gianelo, C.; Bissani, C. A.; Bohnen, H. and Volkweiss, S. J. 1995. Análise de solo, plantas e outros materiais. 2.ed. UFRGS/ Departamento de Solos, Porto Alegre. (Boletim Técnico, 5).

Van Soest, P. J. 1967. Development of a comprehensive system of feeds analysis and its applications to forages. Journal of Animal Science 26:119-128.

Van Soest, P. J. 1994. Nutritional ecology of the ruminant. Cornell University Press, Ithaca, New York.

Vasconcelos, W. A.; Santos, E. M.; Edvan, R. L.; Silva, T. C.; Medeiros, G. R. and Souto Filho, L. T. 2010. Morfometria, produção e composição bromatológica da Maniçoba e Pornunça, em resposta a diferentes fontes de adubação. Revista Trópica 4:36-43.

Wardlaw, I. F. 1990. The control of carbon partioning in plants. The New Phytologist 116:341-381.

Wilson, J. R. 1994. Cell wall characteristics in relation to forage digestion by ruminants. Journal Agricultural Science 122:173-182.

Wobeto, C.; Corrêa, A. D.; Abreu, C. M. P.; Santos, C. D. and Abreu, J. R. 2006. Nutrients in the cassava (Manihot esculenta Crantz) leaf meal at three ages of the plant. Ciência e Tecnologia de Alimentos $26: 865-869$ 